International Journal of Engineering \& Technology, $7(3.31)(2018) 234-239$
International Journal of Engineering \& Technology
SPC
Website: www.sciencepubco.com/index.php/IJET
Research paper

\title{
Identification of Groundwater Potential Zones of Visakhapatnam Urban Area using Integrating Multi Criteria Evaluation with Geographical Information System
}

\author{
K.M. Ganesh ${ }^{1 *}$, G. Jai Sankar ${ }^{2}$, M. Jagannadha Rao ${ }^{3}$, R.Subba Rao ${ }^{4}$ \\ ${ }^{1}$ Department of Civil Engineering, S.R.K.R.Engineering College, Bhimavaram, Andhra Pradesh, India-534204 \\ ${ }^{2}$ Department of Geo-Engineering, College of Engineering, College of Science and Technology, Andhra University, Visakhapatnam, \\ Andhra Pradesh, India-534204 \\ ${ }^{3}$ Department of Geology, College of Science and Technology, Andhra University, Visakhapatnam, Andhra Pradesh, India-534204 \\ ${ }^{4}$ Department of Mathematics, S.R.K.R.Engineering College, Bhimavaram, Andhra Pradesh, India-534204 \\ *Corresponding author E-mail: lakshmimanojna.k@gmail.com
}

\begin{abstract}
Groundwater forms very little quantity when compared to the total water available on the earth. Therefore it is very vital for all living beings especially for human beings. Visakhapatnam, one of the fastest growing industrial city, is situated on the East Coast of India be-

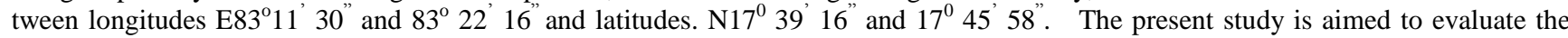
groundwater occurrence using Remote sensing and GIS. Remote sensing data interpretation of visual and digital images gave the immediate information about surface features. From this information the groundwater potential zones are identified. The present study used IRS-IC (March 99) and ID (November 99) LISS-III digital data for comparative land use and land cover categorization and hydrogeomorphological features identification and lineament study. The layers created from Remote sensing data and available ancillary data for index overlay operations for identification of groundwater potential zones in the study area using GIS.
\end{abstract}

Keywords: Groundwater; Groundwater potential zones; G.I.S.; Remote sensing; Index overlay model.

\section{Introduction}

The conventional hydrogeological maps prepared mainly based on groundwater hydrogeological survey provide geological formation wise. The groundwater conditions vary significantly depending up on the Geology, geomorphology, geological structures ( lineaments), slope, drainage \& canals and surface water bodies of the area. Water is absorbed by the earth surface, and it comes back on to the surface through the earth's strata. Ground water conditions at a given site are unique and not uniform. Even the field observation sometimes fails. Evenso, with the help of factor wise analysis, integration and interpretation, the problem can be got over to some extent. An attempt has made to solve this problem using GIS (index-overlay analysis) techniques. The present study area lies in between longitudes E83 ${ }^{\circ} 11^{\prime} 30^{\prime \prime}$ and $83^{\circ} 22^{\prime} 16$ and lat. $\mathrm{N} 17^{0} 39$ ' 16 " and N17 45 ' 58" Fig. 1 .

\section{Methodology}

The methods adopted during the course of investigation have been presented here. Standard scientific methods, which are in vogue were used for both field and laboratory investigations. These methods are presented under following heads. 1. Drainage map preparation 2.Geological map preparation 3.Geomorphological map preparation 4.Lineament map have been prepared through visual interpretation. These maps are converted to vector data from raster by using digitization. 5.Slope map is prepared from DEM

6. A map of land use / land cover, is prepared from remote sensing data using supervised classification method. All required maps have been prepared and assigned weights according to their importance in the groundwater potential point of view as follows.

\subsection{Determination of Weights}

One of the most important applications of G.I.S. is the display and analysis of data support the process of environmental decisionmaking. A decision is a choice between alternatives like actions, locations, objects etc. If the factors are confusing sets, along with the process of aggregation, the standard weights of the linear combination clearly mean interchange between as they change their manner as they behave with other factors when summed up in multiple criteria evaluation. [1] suggested the procedure of pair wise comparison developed by [2], who has shown that the principle Eigenvector of this matrix shows the best fit set of weights. [3 Eastman have implemented this rating scale procedure in a G.I.S. raster with a change allowing a degree of consistency, to locate inconsistencies for an orderly reevaluation. 


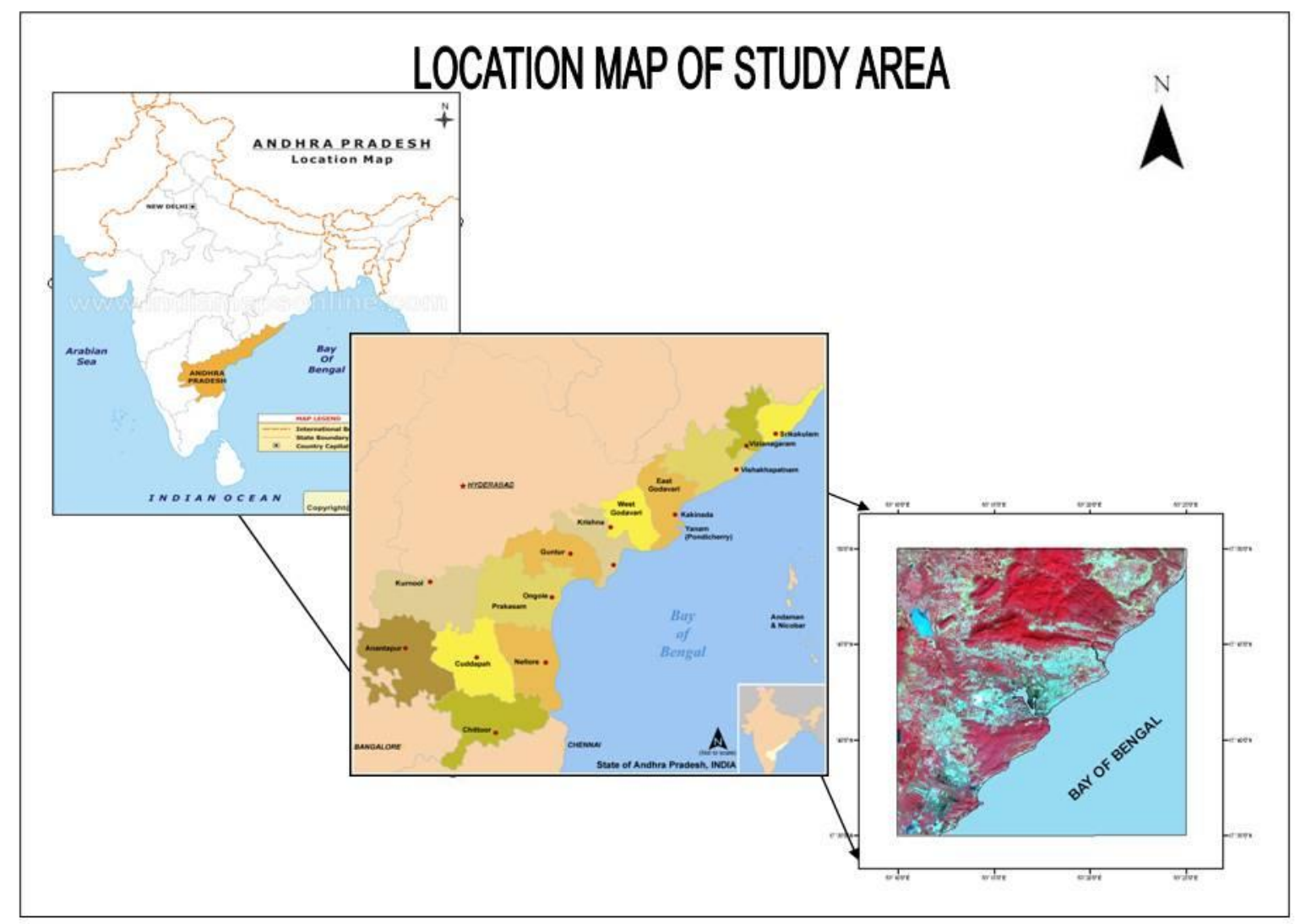

Fig. 1

\section{Groundwater Potential Zones}

\subsection{Geology}

The study area belongs to Precambrian age with the occurrence of meta sediments and igneous bodies. The high hill ranges namely Kailasa, Yarada and Duvvada surround the study area in three directions and other side the Bay of Bengal makes the boundary. In this way the region is endowed with different physiographic features and resulting pictures sequence. In addition to meta sedimentary latest red sediments with calcium carbonate calcretes, dune and beach sands with the important black sand concretions occur. All these features show a different geomorphic features distributed from hinterland to coastal plains.

Garnet sillimanite gneiss (Khondalite) hypersthenes granite (Charnockites) garnetiferous granites (leptynites) Quartzite, pegmatites are the chief rock types occur as bedded and banded as well as massive formations in the study area. About $90 \%$ of the area is occupied by Khondalite group of rocks covering hill ranges of northern part and hillocks in the central part. Garnet - biotite sillimanite gneiss as well as garnet sillimanite gneisses are present in the Yarada hill, hillocks of Waltair and at northern hill ranges to a minor extent. Occurrences of white and gray coloured quartzite's with thickness of few centimeters to thousand meters are also common. Charnockites can be called as hypersthene bearing granitic and mainly occur as two types. They are hypersthene bearing granitic rocks and porphyritic ferro hypersthene granodiorites. In the study area, these rocks occur at airport hill, Maddilapalm, Mudasarlova and pendurthi. At airport hill they are very prominent and other places they occur as small and irregular patches, layers, lenses and bands. They are blue, bluish black and greenish black in colour hard and compact medium to coarse grained with specific gravity varying from 2.7 to 3.3 . Mineralogically they are composed of quartz, feldspar, hypersthene, biotite and garnet. The accessory minerals include, apatite, monazite, zircon, and iron ores. Depending up on variation in felesic minerals the overall composition will vary from acidic to basic.

According to [4] the Charnockites mostly confined to the axis of over turned folds exhibited by Khondalite hill ranges and occasionally shows a stock like intrusive relationship with garnetbiotite, granite (leptynites). Leptinites occur in association with khondalites and Charnockites having variable thickness of few meters to 1500 meters, which are mostly confined, to Waltair area. The geology map Fig. 2A, Hydrogeomorphology map Fig. 2B, Land use/ land cover map Fig. 2C, Drainage buffer map Fig. 2D, Lineament buffer map Fig.2E and slope map Fig. 2F of the area are shown in Fig.2.

The study of Hydromorphological and hydrogeological zones depending upon the physical, geological, hydrogeological and geomorphological characteristics and so it is done by remote sensing to get the required data.

Besides these, many other studies in India and abroad have been carried out for the hydromorphogeological evaluations using remote sensing data. Hence, the through survey of literature proved that, the remote sensing is a quick and efficient method for demarcating and evaluating the zones of ground water. Standard remote sensing techniques are used in the study area to determine the hydrogeomorphological features. 


\subsection{Hydromorphogeological Features Hilly Terrain}

The area under study is understood using satellite data IRS-1D LISS-III and IRS- IC-LISS-III digital and FCC imagery has been used.

Based on these studies, the area is divided into 1. plains (Now mostly built up area), 2. Hilly terrain, 3. Vally fills Fig .2.

In the existing lithological groups various geomorphic units have been interpreted from satellite data and hydromorphogeological map is prepared by incorporating the geological, structural, groundwater data. The major geomorphological units identified in the study area described below and methodology was followed has been described in methodology.

\subsection{Lineaments}

A simple or composite linear features of a surface is called lineament. The parts of the lineament have a rectilinear or slightly curvilinear alignment and differ from the adjacent features, showing subsurface phenomena. In the study area a number of lineaments have been observed and each lineament has different trend and lengths.

Lineaments play an important role in the development of groundwater zones by helping the precipitation to percolate creating the secondary porosity and the weak zones, which help the precipitation to percolate downwards to create the secondary porosity and the weak zones, which help the precipitation to percolate downwards to create an aquifer. In hard rock terrain these lineaments create the opening which increase the permeability of the rock and forms a trap for groundwater to form an aquifer. Therefore, in any study related to groundwater or surface water delineation of lineaments are very important. The lineaments present in area are also play an active role to circulate the pollutants from one place to another place.

To establish the zones of influence along these lineaments buffers are created using operation distance and slicing. Along lineaments a buffer zone of $25 \mathrm{~m}, 50 \mathrm{~m}, 75 \mathrm{~m}, 125 \mathrm{~m}$ has created these zones is shown in Fig. 2. These buffers are considered as a layer and weightages are calculated for analysis.

The lineaments in the present study are mapped with the help of satellite imagery of IRS IC-LISS III data. The major lineament direction is NE-SW and NW-SE. These are classified in to four classes and are

1. Major lineament (Buffer-125mts)

2. Minor lineament (Buffer-75mts)

3. Macro lineament (Buffer-50mts)

4. Micro lineament (Buffer-25mts).

\subsection{Slope}

Slope is the most important parameter in natural resources study For groundwater study, delineation of slope classes in appropriate manner is very important because slope is the main factor, which indicate the major run off in underground. To prepare the slope map GIS has got magnificent capabilities of interpolation by which the accuracy of slope delineation increases. Survey of India topo sheet on 1:50,000 scale is used to delineate the contours at $20 \mathrm{~m}$ intervals. The contours are digitized, edited and rastarized. From interpolation of contours, the digital elevation model is prepared. On this model filters Dfdx and Dfdy are applied. Then slope percentage is calculated with the help of equation given below.

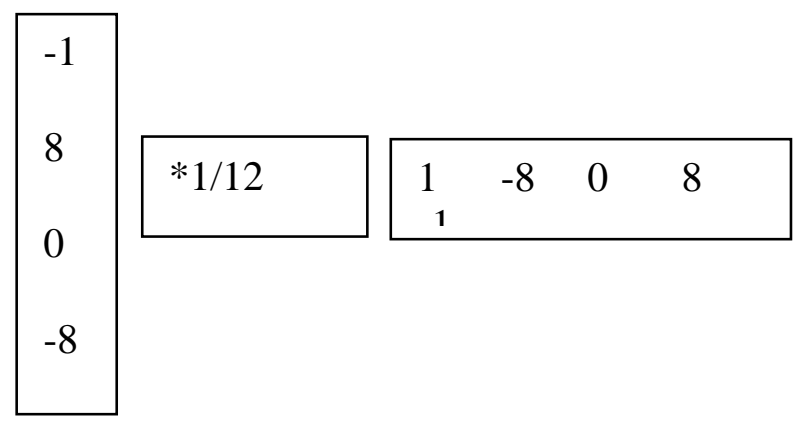

Df Dx filter

Df Dy filter

Slope per $=(($ HPY $($ Dx, Dy0 $)) /($ Pixsize $($ DEM $) * 100$

The slope percentage map (Fig .2) is further classified using the SLICING operation. The classes that are delineated are.

$\begin{array}{ll}\text { Class } & \text { Slope \% } \\ \text { Gentle } & 0-5 \% \\ \text { Moderately gentle } & 5-10 \% \\ \text { Moderate } & 10-15 \% \\ \text { Steep } & 15-35 \% \\ \text { Very steep } & \text { above }-35 \%\end{array}$

\subsection{Land Use / Land Cover Studies}

Land use/land cover and vegetation resources utilization, conservation and management are the basic requisite for land use/land cover information. According to [5] land use mean show a piece of land is used and land cover means the things present on the surface of the land [6]. The land use/ land cover give very good idea of the groundwater and the change in them indicate the change in hydrogeological condition. Anomalous growth of vegetation or the presence of potential and healthy vegetation in low lying areas are indicative of the presence of high moisture zones and shallow aquifers.

While interpreting the land use/land cover of the area of study, various features are the area have been classified with the help of the satellite data (Fig. 2).

\subsection{Drainage Buffer}

The drainage network of the area under/study with five orders of streams influence the groundwater potential. It has been prepared and created buffer for the drainage and shown in Fig. 2.

\section{Data Base Organisation And Analysis}

To achieve objective of the present study suitable methodology is inevitable to create a data base which is equally compatible to the methodology. Thus it becomes mandatory to organize the database to enable smoother analysis and trying out every possibility of inter thematic and inter class dependencies and variabilities operating in nature. This is an attempt to use the capabilities of GIS (ILWIS 2.2.3) along with index overlay model to generate the out put for groundwater exploration.

Thematic maps, like geology, hydromorphogelogy, land use /land cover, lineament buffer map, drainage buffer map and slope map were generated and digitized. The digitized maps were edited and listed to suite as an input variable in GIS analysis. The whole process has given an output of digital database required for the study. 


\subsection{Analysis for Groundwater Potential Zonation}

The input layers, considered for the analysis of groundwater potential zonation are geology map, hydrogeomorphological map, lineament buffer map, slope map, land use / land cover map and drainage buffer map. There are several methods available to determine inter class dependencies or inter map dependencies. Here an attempt has been made to use multi class maps in index overlay model.

\subsection{Index Overlay Model with Multi Class Maps}

The weights were assigned by the method suggested by [7] and [8]. In this case the map classes occurring on each input map are assigned different scores, as well as the maps themselves receiving different weights as before. It is convenient to define the scores in an attribute table for each input map.

The averages score is then derived by

$$
\overline{\mathrm{S}}=\frac{\sum \mathrm{Sij} \mathrm{Wi}}{\sum \mathrm{Wi}}
$$

$\mathrm{S}$ is the weighted score for an area object (polygon, pixel) Wi is the weighted score for the $i$-th input map and $\mathrm{Sij}$ is the score for the $\mathrm{j}$ - th class of the $\mathrm{i}$-th map, the values of $\mathrm{j}$ depending on the class actually occurring at the current location.

Each map must be associated with an editor, for access by the modeling procedure. The attribute table can then be modified without changing the procedure. Attribute table containing scores are shown in Tables 1 to 6 for the groundwater potential zones.

\subsection{Derivation of Weights}

The weights for the 6 input maps for groundwater potential zoning have been assigned and added together. The Fig. 2 shows all the six thematic maps. Tables 1 to 6 show weights of individual class of the each map.

Table No.1 :Geology Map

\begin{tabular}{|c|l|c|}
\hline S.No. & \multicolumn{1}{|c|}{ Class } & Weight \\
\hline 1 & Beach sand & 5.0 \\
\hline 2 & Charnockites & 2.0 \\
\hline 3 & Khondalite & 4.0 \\
\hline 4 & Khondalite \& Leptynite & 3.0 \\
\hline 5 & Marshy land & 7.0 \\
\hline 6 & Residual soil & 10.0 \\
\hline 7 & River alluvium & 9.0 \\
\hline 8 & Water body & 0.0 \\
\hline
\end{tabular}

Table No.2 :Hydrogeomorphological map

\begin{tabular}{|c|l|c|}
\hline S. No & \multicolumn{1}{|c|}{ Class } & Weight \\
\hline 1 & Alluvial plains & 9.0 \\
\hline 2 & Beach sand & 6.0 \\
\hline 3 & Colluvial fan & 7.0 \\
\hline 4 & Deeply weathered pediment & 10.0 \\
\hline 5 & Disected slope & 4.0 \\
\hline 6 & Inselberg & 0.0 \\
\hline 7 & marshy area \& Marine clay & 5.0 \\
\hline 8 & Moderately weathered pediment & 9.0 \\
\hline 9 & Pediment & 2.0 \\
\hline 10 & Red sediment/Bad land & 7.0 \\
\hline 11 & Residual hill & 2.0 \\
\hline 12 & Residual hill & 2.0 \\
\hline 13 & Shallow weathered pediment & 8.0 \\
\hline 14 & Structural hill & 1.0 \\
\hline 15 & Water body & 0.0 \\
\hline
\end{tabular}

Table No.3: Land use / Land cover classes

\begin{tabular}{|c|l|c|}
\hline S.No & \multicolumn{1}{|c|}{ Class } & Weight \\
\hline 1 & Barren soil \&barren rock & 5.0 \\
\hline 2 & Built-up land & 5.0 \\
\hline 3 & Cropland \& Fallow land & 10.0 \\
\hline 4 & Degraded forest \&Shrubs & 6.0 \\
\hline 5 & Forest plantation & 9.0 \\
\hline 6 & Marshy/Salt effected area & 5.0 \\
\hline 7 & Red sand soil 1\& Beach sands & 6.0 \\
\hline 8 & Scrubs/Shrubs & 7.0 \\
\hline 9 & water & 0.0 \\
\hline
\end{tabular}

Table No.4 :Lineaments Buffer

\begin{tabular}{|c|l|c|}
\hline S. No. & \multicolumn{1}{|c|}{ Class } & Weight \\
\hline $\mathbf{1}$ & Major lineament & 4.0 \\
\hline $\mathbf{2}$ & Minor lineament & 3.0 \\
\hline $\mathbf{3}$ & Macro lineament & 2.0 \\
\hline $\mathbf{4}$ & Micro lineament & 1.0 \\
\hline
\end{tabular}

Table No.5: Drainage Buffer

\begin{tabular}{|c|l|c|}
\hline S. No & Class & Weight \\
\hline 1 & First Order Stream & 1.0 \\
\hline 2 & Second order Stream & 2.0 \\
\hline 3 & Third order stream & 3.0 \\
\hline 4 & Fourth order Stream & 4.0 \\
\hline 5 & Fifth order Stream & 5.0 \\
\hline
\end{tabular}

Table No.6: Slope

\begin{tabular}{|l|l|c|}
\hline S.No. & Class & Weight \\
\hline 1 & Water & 0.0 \\
\hline 2 & gentle slope & 5.0 \\
\hline 3 & Moderately gentle & 4.0 \\
\hline 4 & Moderate slope & 3.0 \\
\hline 5 & low steep & 2.0 \\
\hline 6 & steep slope & 1.0 \\
\hline
\end{tabular}

\subsection{Map Weights}

$\mathrm{M} 1=5 *$ (class (geology)

M2 $=9 *($ class $($ Hydromorphogeology $)$

M3 $=6 *$ (class (Land use / land cover)

M4 $=8 *$ (class (Slope categories)

M5=7* (class (lineament buffer)

M6 $=4 *$ (class (drainage buffer)

Calculate sum of weighted conditions and divided by normalization factor

New $=((* \mathrm{M} 1+* \mathrm{M} 2+* \mathrm{M} 3+* \mathrm{M} 4+* \mathrm{M} 5+* \mathrm{M} 6)) / \mathrm{SUM}$ the derived map shown in Fig.3. 


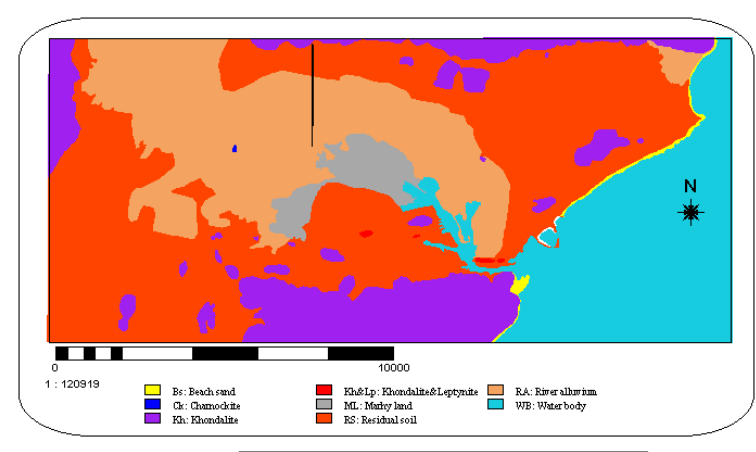

A. Geology Map

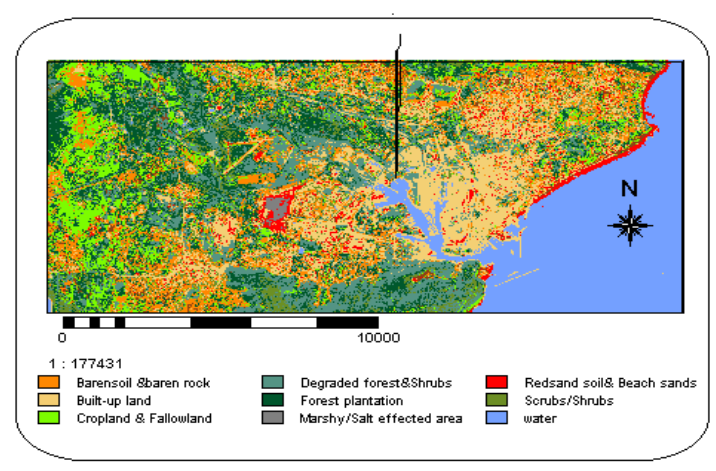

C. Land Use Land Cover Map

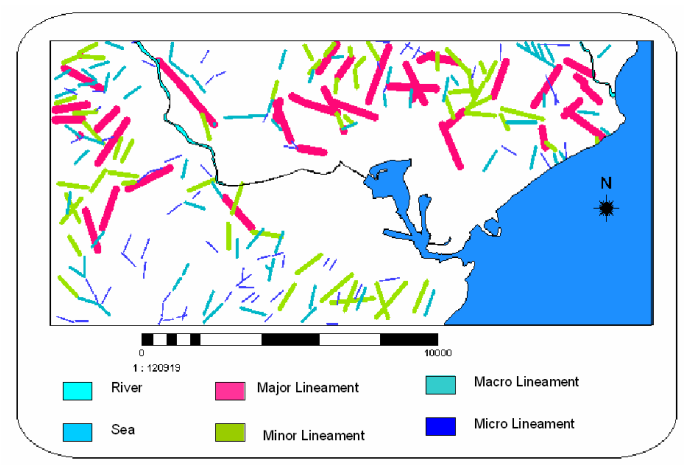

E. Lineament Buffer Map

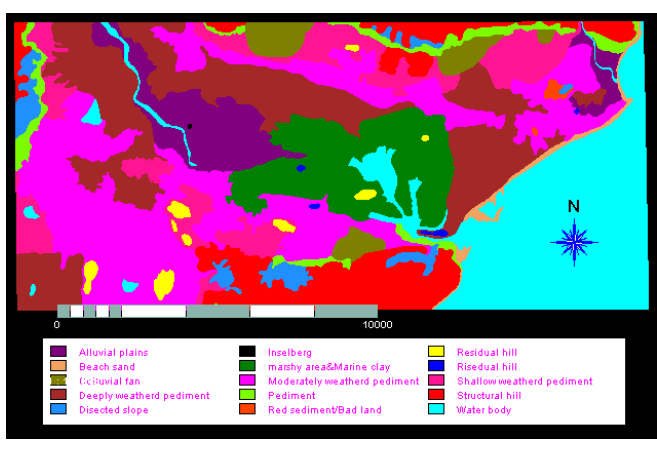

B. Hydrogeomorphology Map

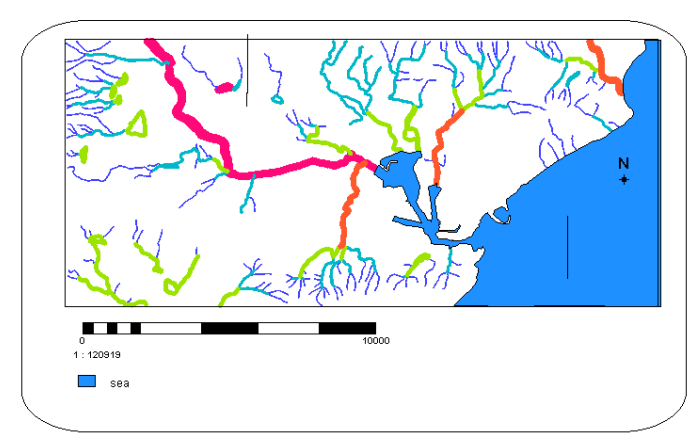

D. Drainage Buffer Map

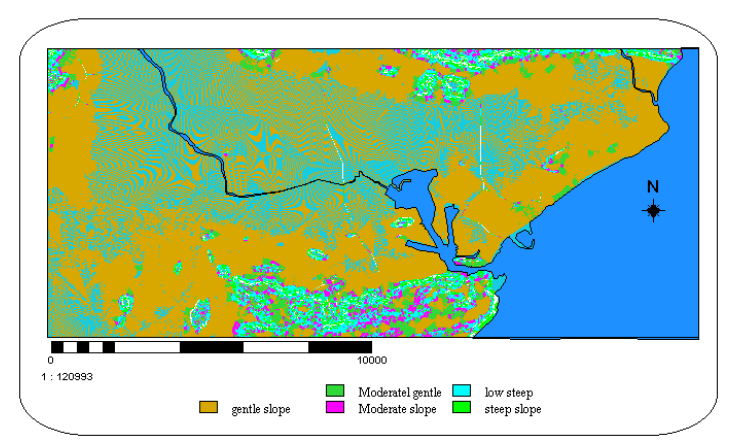

F. Slope Map 


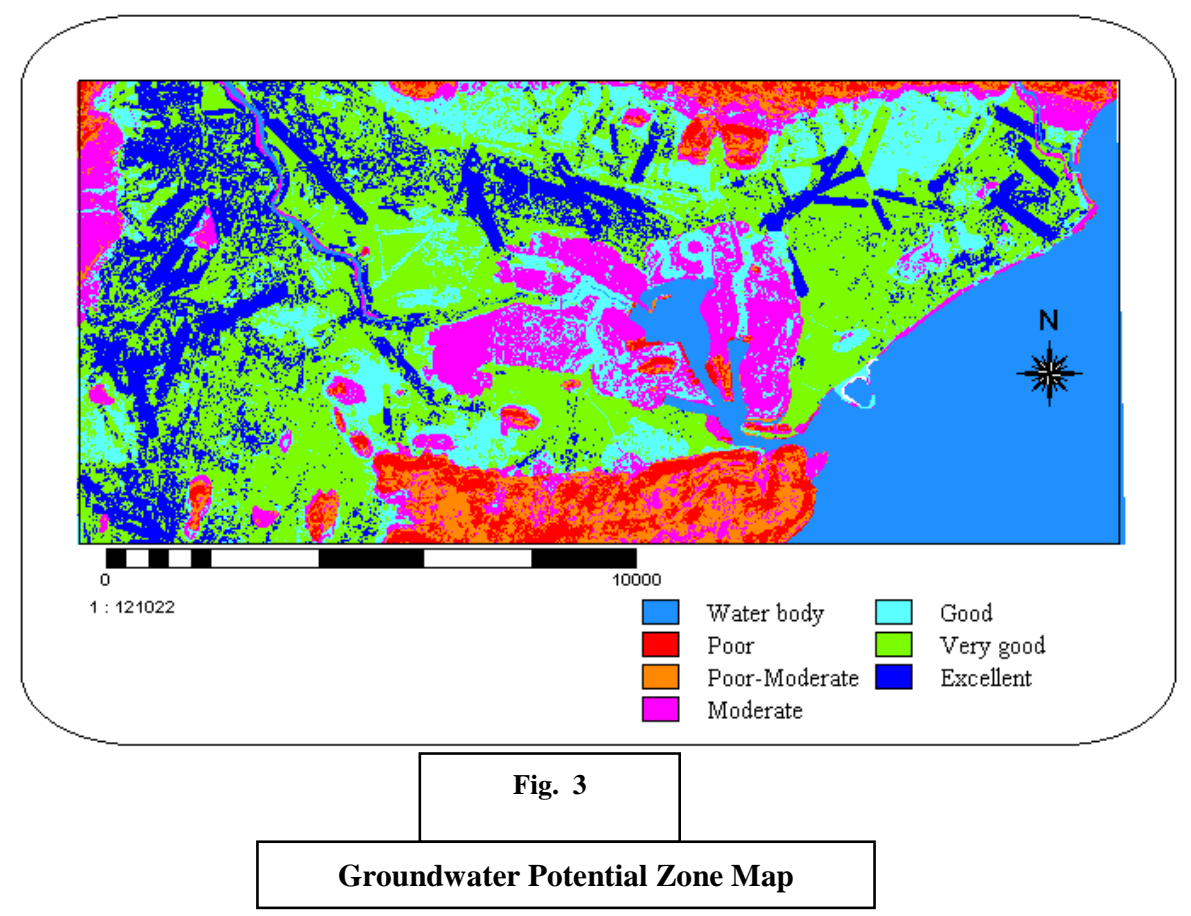

\section{Conclusions}

In this study the groundwater potential zones have been identified in Visakhapatnam urban and industrial area. Based on the field data and remote sensing inputs a resultant map is prepared in GIS environment. According to the resultant map of the study area, it has been divided in to five zones on groundwater prospective point of view, which are presented below.

- Excellent groundwater potential zone: This zone is associated with highly weathered Khondalite, high-density lineament areas hydrogeologically deeply weathered pediment with gentle slope, high vegetation and irrigated land use pattern.

- Very good groundwater potential zones: This zone is a mainly delineated in deeply weathered pediment to moderately weathered zone with alluvial plain areas. In this area slope is gentle lineaments are very high density, which are play major role in developing the secondary porosity having very good groundwater condition.

- Good groundwater potential zones: This zone is found mainly in moderately weathered pediment zone, supported by the presence of lineaments and gentle slope areas. The rock types are Khondalite of highly weathered nature.

- Moderate groundwater potential Zones: This zone is mainly confined to areas having moderate slope with minor lineaments and shallow weathered pediment zone.

- Poor to moderate groundwater potential zones: This zone is existing where the hill slopes and pediment zone areas with thin layer of weathered zone.

- Poor to nil groundwater potential zones: The zone is purely confined to the hilly region having poor to nil groundwater, sources.

\section{Acknowledgement}

The authors gratefully acknowledge the Principal and Management of S.R.K..R.Engineering College (Autonomous), Bhimavaram, W.G.District, Andhra Pradesh, India for his outstanding help with this paper.

\section{References}

[1] Rao.M. Sastry.S.V.C.Yader.P.D, Kharod.K, Phaton.S.K, Dhinwa.P,Majumda.K, Samptkumar.D, Patkar.V.N, Phatak.V.K. (1991) A weighted index model for urban suitability assessment-aGIS approach, Bombay, Bombay Metropolitian Regional Development Authority.

[2] Saaty, T.L., The analytical hierarchy process, McGraw Hill, New York, 1980.

[3] Eastman J.R Jin W.Kyem.P.A.K.Toledano.J. Raster procedure for multi criteria / multi objective decisions, Photogrammetric Engineering and Remote sensing (1993).

[4] Mahadevan, C. and Sathapathi, N., The origin of Waltair high lands (1949), Indian Geographical Journal, Vol. 24, pp. 1-22.

[5] Sabins, F.F. Jr., Remote sensing, Principles and Interpretation, W.H.Frernan and Co., San Francisco, (1987), Catif,pp 429.

[6] N.R.S.A., Manual of procedure for waste lands mapping using remote sensing techniques (1989), Government of India.

[7] Yager.R. ,On ordered weighted averaging aggregation operators in multi criteria decision making, IEEE, Transactions on System Man and Cybernetics, (1988), Vol. 8: pp. 183-190.

[8] Voogd,H., Multi-criteria evaluation for urban and regional planning. London, Pion. ( 1983). 